\title{
Effect of Free Ammonia, Free Nitrous Acid, and Alkalinity on the Partial Nitrification of Pretreated Pig Slurry, Using an Alternating Oxic/Anoxic SBR
}

\author{
Marisol Belmonte, ${ }^{1,2,3}$ Chia-Fang Hsieh, ${ }^{1}$ José Luis Campos, ${ }^{4}$ Lorna Guerrero, ${ }^{5}$ \\ Ramón Méndez, ${ }^{6}$ Anuska Mosquera-Corral, ${ }^{6}$ and Gladys Vidal ${ }^{1}$ \\ ${ }^{1}$ Engineering and Environmental Biotechnology Group, Environmental Science Faculty \& Center EULA-Chile, \\ University of Concepción, P.O. Box 160-C, Concepción, Chile \\ ${ }^{2}$ School of Biochemical Engineering, Pontificia Universidad Católica de Valparaíso, 2362803 Valparaíso, Chile \\ ${ }^{3}$ Laboratory of Biotechnology, Environment and Engineering, Faculty of Engineering, University of Playa Ancha, \\ 2340000 Valparaíso, Chile \\ ${ }^{4}$ Facultad de Ingeniería y Ciencias, Universidad Adolfo Ibáñez, 2503500 Viña del Mar, Chile \\ ${ }^{5}$ Department of Chemical and Environmental Engineering, University Federico Santa María, 2390123 Valparaíso, Chile \\ ${ }^{6}$ Department of Chemical Engineering, School of Engineering, University of Santiago de Compostela, \\ 15782 Santiago de Compostela, Spain
}

Correspondence should be addressed to Marisol Belmonte; marisol.belmonte@upla.cl

Received 18 May 2017; Accepted 1 August 2017; Published 6 September 2017

Academic Editor: Giuseppe Olivieri

Copyright (C) 2017 Marisol Belmonte et al. This is an open access article distributed under the Creative Commons Attribution License, which permits unrestricted use, distribution, and reproduction in any medium, provided the original work is properly cited.

The effect of free ammonia $\left(\mathrm{NH}_{3}\right.$ or $\left.\mathrm{FA}\right)$, free nitrous acid $\left(\mathrm{HNO}_{2}\right.$ or FNA), and total alkalinity (TA) on the performance of a partial nitrification $(\mathrm{PN})$ sequencing batch reactor (SBR) treating anaerobically pretreated pig slurry was studied. The SBR was operated under alternating oxic/anoxic (O/A) conditions and was fed during anoxic phases. This strategy allowed using organic matter to partially remove nitrite $\left(\mathrm{NO}_{2}{ }^{-}\right)$and nitrate $\left(\mathrm{NO}_{3}{ }^{-}\right)$generated during oxic phases. The desired $\mathrm{NH}_{4}{ }^{+}$to $\mathrm{NO}_{2}{ }^{-}$ratio of $1.3 \mathrm{~g} \mathrm{~N} / \mathrm{g} \mathrm{N}$ was obtained when an Ammonium Loading Rate (ALR) of $0.09 \mathrm{~g} \mathrm{NH}_{4}{ }^{+}-\mathrm{N} / \mathrm{L} \cdot \mathrm{d}$ was applied. The system was operated at a solid retention time (SRT) of 15-20 d and dissolved oxygen (DO) levels higher than $3 \mathrm{mg} \mathrm{O}_{2} / \mathrm{L}$ during the whole operational period. PN mainly occurred caused by the inhibitory effect of FNA on nitrite oxidizing bacteria (NOB). Once $\mathrm{HNO}_{2}$ concentration was negligible, $\mathrm{NH}_{4}{ }^{+}$was fully oxidized to $\mathrm{NO}_{3}{ }^{-}$in spite of the presence of FA. The use of biomass acclimated to ammonium as inoculum avoided a possible effect of FA on NOB activity.

\section{Introduction}

The intensive swine production is creating scenarios where generated waste is not correctly disposed, exceeding the assimilation capability of the soil-water-plant ecosystem of the crop lands [1]. The anaerobic digestion is the most used technology to treat this kind of wastes [2]. In this process, high removal efficiencies of carbonaceous compounds contained in the wastewater are achieved while nitrogen removal is scarce, only due to biomass growth. Since the effluent from the anaerobic digester has a low $\mathrm{C} / \mathrm{N}$ ratio, to perform nitrogen removal by the combination of nitrification (sequential ammonium $\left(\mathrm{NH}_{4}{ }^{+}\right)$oxidation to nitrite $\left(\mathrm{NO}_{2}{ }^{-}\right)$ and nitrate $\left(\mathrm{NO}_{3}{ }^{-}\right)$) and denitrification (nitrate or nitrite reduction to nitrogen gas $\left(\mathrm{N}_{2}\right)$ ) processes is not economically feasible due to the requirements of organic matter. The application of the combined partial nitrification (oxidation of ammonium to nitrite with around 50\% efficiency) and anammox (combination of previously generated nitrite and ammonium to produce nitrogen gas) processes could avoid this drawback. However, some studies reflected problematic situations for nitrogen removal in this way due to the presence 


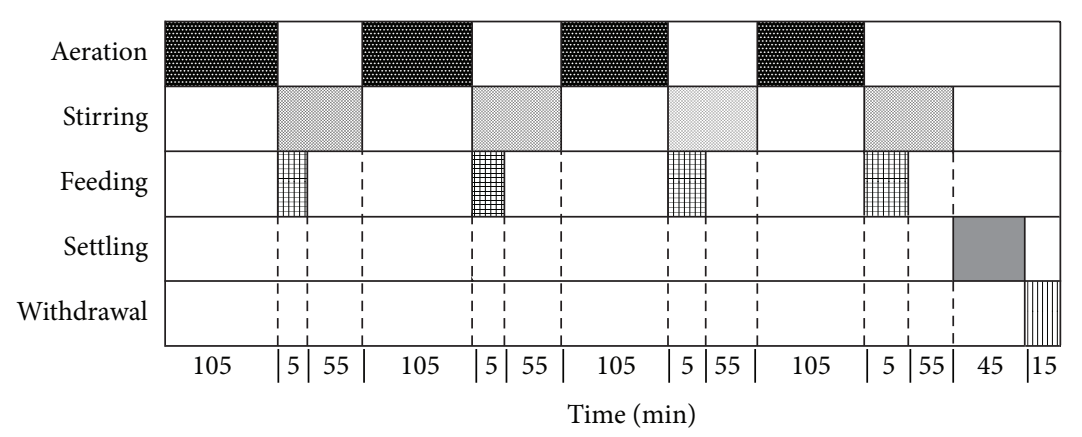

FIGURE 1: Distribution of the operational cycle.

of relevant concentrations of residual organic matter in the treated effluent [3]. In this sense, Wett et al. [4] proposed to treat a municipal wastewater, with a low $\mathrm{C} / \mathrm{N}$ ratio, in a partial nitrification unit operated in alternated oxic and anoxic periods in order to promote the use of the organic matter present for denitrification. This strategy together with the control of the solid retention time (SRT) also allowed suppressing the growth of nitrite oxidizers when the unit was operated at low temperature and low ammonium concentrations and, therefore, improving the stability of partial nitrification. Moreover, as the organic matter was removed by denitrification, alkalinity was generated which partially compensated for the alkalinity consumption due to partial nitrification.

During the treatment of wastewater with high ammonium concentrations, as the effluent of pig slurry coming from the anaerobic digestion, the presence of free ammonia $\left(\mathrm{NH}_{3}\right.$ or FA) and/or free nitrous acid $\left(\mathrm{HNO}_{2}\right.$ or FNA) can affect the performance of the partial nitrification process. These compounds can cause inhibition of nitrifying and denitrifying bacteria and provoke the nitrite accumulation in the system $[5,6]$. The nitrifying bacteria are inhibited at concentrations of FA and FNA within $0.1-150 \mathrm{mg} \mathrm{NH}_{3}-$ $\mathrm{N} / \mathrm{L}$ and $0.2-2.8 \mathrm{mg} \mathrm{HNO}_{2}-\mathrm{N} / \mathrm{L}$, respectively [5], while the effect of FNA on denitrifying bacteria was observed within 0.01-0.20 $\mathrm{mg} \mathrm{HNO}_{2}-\mathrm{N} / \mathrm{L}$ [7]. Another factor to be considered is the inlet total alkalinity/ammonium ratio $\left(\mathrm{TA} / \mathrm{NH}_{4}{ }^{+}-\mathrm{N}\right)$ since it will determine the $\mathrm{pH}$ value inside the reactor and, therefore, the concentrations of FNA and/or FA [8-10].

In the present research the effect of FA, FNA, and total alkalinity/ammonium ratio on the performance of a partial nitrification sequencing batch reactor (SBR) operated under alternating oxic/anoxic conditions was studied. An anaerobically pretreated pig slurry and acclimated biomass to high ammonium concentrations were used as feeding and inoculum, respectively. The operational conditions were adjusted to achieve the desired nitrite to ammonium ratio in the effluent and promote the consumption of the present organic matter by means of the denitrification process.

\section{Materials and Methods}

2.1. Reactor SBR Description and Operational Conditions. A laboratory scale SBR with a working volume of $1.5 \mathrm{~L}$ and a total volume of $2.5 \mathrm{~L}$ was used. Dimensions of the unit were height of $540 \mathrm{~mm}(H)$, inner diameter of $77 \mathrm{~mm}(D)$, and the $H / D$ ratio of 7 . Oxygen was supplied by means of a ceramic air diffuser located at the bottom of the reactor connected to an air pump. The system was equipped with a mechanical stirrer operated at $80 \mathrm{RPM}$. The reactor was maintained in a thermostated chamber at $33 \pm 2^{\circ} \mathrm{C}$. The $\mathrm{pH}$ was not controlled and ranged between 6.2 and 8.5. A programmable logic controller (PLC) was used to control the cycle.

The reactor was operated in cycles of $12 \mathrm{~h}$ distributed as shown in Figure 1. The volume exchange ratio was fixed at $8.3 \%$ and the hydraulic retention time (HRT) was of 6 days. The DO was supplied only during the oxic period and its concentration was kept higher than $3 \mathrm{mg} \mathrm{O}_{2} / \mathrm{L}$. In the anoxic phase the mixture inside the reactor was achieved through mechanical stirring.

The reactor was fed with the effluent coming from an anaerobic digester treating diluted pig slurry [2], whose total alkalinity/ $\mathrm{NH}_{4}{ }^{+}$ratio ranged from 4.0 to $9.4 \mathrm{~g} / \mathrm{g}$. The reactor was operated during 270 days divided into three stages according to the inlet ammonium concentrations of 350, 550, and $880 \mathrm{mg} \mathrm{NH}_{4}{ }^{+}-\mathrm{N} / \mathrm{L}$, which corresponded to applying Ammonium Loading Rates (ALRs) of 0.06, 0.09, and $0.15 \mathrm{~g} \mathrm{NH}_{4}{ }^{+}-\mathrm{N} / \mathrm{L} \cdot \mathrm{d}$, respectively (Table 1 ). The SRT was not controlled and ranged from 15 to $20 \mathrm{~d}$ during the whole operational period.

2.2. Activity Assays. Periodical samples of biomass were collected from the reactor during the operational stages to evaluate their specific ammonium and nitrite oxidizing activities ( $\mathrm{AOB}$ and $\mathrm{NOB}$, resp.) and specific denitrifying activity (SDA). The specific nitrifying activity (ammonium and nitrite oxidizing) of the biomass was determined by respirometric assays, applying the methodology described by López-Fiuza et al. [11], while the maximum SDA of the sludge was determined according to the methodology proposed by Buys et al. [12].

2.3. Inoculum. The SBR was inoculated with $5 \mathrm{~g}$ volatile suspended solids (VSS)/L of activated sludge collected from an aerobic reactor, used to remove both organic matter and nitrogen from pig slurry, located in the Region of the Libertador Bernardo O'Higgins, Chile. The initial specific 
TABLE 1: Characterization of the different operational stages of the SBR reactor.

\begin{tabular}{|c|c|c|c|c|c|c|c|}
\hline \multirow{3}{*}{ Parameter } & \multirow{3}{*}{ Unit } & \multicolumn{6}{|c|}{ Stage } \\
\hline & & \multicolumn{2}{|c|}{ I } & \multicolumn{2}{|c|}{ II } & \multicolumn{2}{|c|}{ III } \\
\hline & & Influent & Effluent & Influent & Effluent & Influent & Effluent \\
\hline Operation time & $\mathrm{d}$ & \multicolumn{2}{|c|}{$0-75$} & \multicolumn{2}{|c|}{$76-190$} & \multicolumn{2}{|c|}{$191-270$} \\
\hline ALRs & $\mathrm{g} \mathrm{NH}_{4}^{+}-\mathrm{N} / \mathrm{L} \cdot \mathrm{d}$ & \multicolumn{2}{|c|}{0.06} & \multicolumn{2}{|c|}{0.09} & \multicolumn{2}{|c|}{0.15} \\
\hline Total alkalinity $/ \mathrm{NH}_{4}{ }^{+}-\mathrm{N}$ & $\mathrm{g} / \mathrm{g}$ & $9.4 \pm 0.0$ & - & $7.5 \pm 0.0$ & - & $4.1 \pm 0.0^{*}$ & - \\
\hline $\mathrm{pH}$ & & $7.5 \pm 0.1$ & $7.4 \pm 1.3$ & $7.5 \pm 0.1$ & $6.8 \pm 0.9$ & $7.5 \pm 0.1$ & $7.2 \pm 1.3$ \\
\hline $\mathrm{COD}_{\mathrm{S}}$ & $\mathrm{mg} / \mathrm{L}$ & $734 \pm 85$ & $415 \pm 28$ & $801 \pm 100$ & $363 \pm 189$ & $1907 \pm 319$ & $293 \pm 58$ \\
\hline $\mathrm{NH}_{4}^{+}-\mathrm{N}$ & $\mathrm{mg} / \mathrm{L}$ & $350 \pm 26$ & $82 \pm 25$ & $550 \pm 67$ & $128 \pm 77$ & $880 \pm 100$ & $102 \pm 60$ \\
\hline $\mathrm{NO}_{2}{ }^{-}-\mathrm{N}$ & $\mathrm{mg} / \mathrm{L}$ & $<1.0$ & $174 \pm 32$ & $<1.0$ & $165 \pm 86^{*}$ & $<1.0$ & $2 \pm 2$ \\
\hline $\mathrm{NO}_{3}{ }^{-}-\mathrm{N}$ & $\mathrm{mg} / \mathrm{L}$ & $<1.0$ & $45 \pm 5$ & $<1.0$ & $42 \pm 17^{*}$ & $<1.0$ & $293 \pm 138$ \\
\hline $\mathrm{NO}_{2}{ }^{-}-\mathrm{N} / \mathrm{NH}_{4}{ }^{+}-\mathrm{N}$ & $\mathrm{g} / \mathrm{g}$ & - & $2.1 \pm 0.5$ & - & $1.3 \pm 0.5$ & - & $<0.1 \pm<0.1$ \\
\hline NIT & $\%$ & \multicolumn{2}{|c|}{$79 \pm 5$} & \multicolumn{2}{|c|}{$76 \pm 5$} & \multicolumn{2}{|c|}{$86 \pm 11$} \\
\hline NAR & $\%$ & \multicolumn{2}{|c|}{$78 \pm 2$} & \multicolumn{2}{|c|}{$83 \pm 6^{* *}$} & \multicolumn{2}{|c|}{$1 \pm<0.1$} \\
\hline $\mathrm{N}_{\text {removed }}$ & $\%$ & \multicolumn{2}{|c|}{$21 \pm 13$} & \multicolumn{2}{|c|}{$30 \pm 7$} & \multicolumn{2}{|c|}{$45 \pm 19$} \\
\hline $\mathrm{COD}_{\text {removed }}$ & $\%$ & \multicolumn{2}{|c|}{$39 \pm 9$} & \multicolumn{2}{|c|}{$54 \pm 11$} & \multicolumn{2}{|c|}{$85 \pm 3$} \\
\hline $\mathrm{COD}_{\text {removed }} / \mathrm{N}_{\text {removed }}$ & $\mathrm{g} / \mathrm{g}$ & \multicolumn{2}{|c|}{$2.8 \pm 1$} & \multicolumn{2}{|c|}{$2.6 \pm 0.4$} & \multicolumn{2}{|c|}{$3.5 \pm 0.5$} \\
\hline
\end{tabular}

${ }^{*}$ Sodium bicarbonate $\left(\mathrm{NaHCO}_{3}\right)$ was added to the influent to keep it at total alkalinity/ $\mathrm{NH}_{4}{ }^{+}-\mathrm{N}$ ratio of $4.1 \mathrm{~g} / \mathrm{g}$. ${ }^{* *}$ During the stable period (days 76 to 160 ).

nitrifying activities obtained for $\mathrm{AOB}$ and NOB were of $27 \mathrm{mg}$ $\mathrm{NH}_{4}{ }^{+}-\mathrm{N} / \mathrm{g}$ VSS.d and $19 \mathrm{mg} \mathrm{NO}_{2}{ }^{-}-\mathrm{N} / \mathrm{g}$ VSS.d, respectively, and the initial SDA was of $72 \mathrm{mg} \mathrm{NO}_{2}{ }^{-}-\mathrm{N} / \mathrm{g}$ VSS.d.

2.4. Analytical Methods. Concentrations of soluble chemical oxygen demand $\left(\mathrm{COD}_{\mathrm{S}}\right), \mathrm{VSS}, \mathrm{NH}_{4}{ }^{+}, \mathrm{NO}_{2}{ }^{-}$, and $\mathrm{NO}_{3}{ }^{-}$ were determined according to the Standard Methods [13]. Total alkalinity was determined by titration according to the methodology described by Ripley et al. [14]. The $\mathrm{pH}$ value and DO concentrations were measured using specific electrodes (pH: sensor Multiparameter Oakton PC650 model; DO: sensor Oxi 330 WTW).

2.5. Calculations. The nitrification (NIT) and nitrite accumulation ratio (NAR) percentages were calculated according to the following equations:

$$
\begin{aligned}
\mathrm{NIT} & =\frac{\mathrm{NH}_{4}{ }^{+}-\mathrm{N}_{i}-\mathrm{NH}_{4}{ }^{+}-\mathrm{N}_{e}}{\mathrm{NH}_{4}{ }^{+}-\mathrm{N}_{i}} \cdot 100 \\
\mathrm{NAR} & =\frac{\mathrm{NO}_{2}{ }^{-}-\mathrm{N}_{e}}{\mathrm{NO}_{3}{ }^{-}-\mathrm{N}_{e}+\mathrm{NO}_{2}{ }^{-}-\mathrm{N}_{e}} \cdot 100,
\end{aligned}
$$

where $\mathrm{NH}_{4}{ }^{+}-\mathrm{N}_{i}$ and $\mathrm{NH}_{4}{ }^{+}-\mathrm{N}_{e}$ are the concentrations of ammonia in the influent and effluent, respectively, and $\mathrm{NO}_{2}{ }^{-}$$\mathrm{N}_{e}$ and $\mathrm{NO}_{3}{ }^{-}-\mathrm{N}_{e}$ are the concentrations of nitrite and nitrate in the effluent, respectively.

The ratio between the amount of organic matter removed and nitrogen removed $\left(\mathrm{COD}_{\text {removed }} / \mathrm{N}_{\text {removed }}, \mathrm{g} \mathrm{COD}_{\mathrm{S}} / \mathrm{g} \mathrm{N}\right)$ was calculated according to the following equation:

$$
\begin{aligned}
& \frac{\mathrm{COD}_{\text {removed }}}{\mathrm{N}_{\text {removed }}} \\
& =\frac{\left(\mathrm{COD}_{i}-\mathrm{COD}_{e}\right)}{\mathrm{NH}_{4}{ }^{+}-\mathrm{N}_{i}-\left(\mathrm{NO}_{3}{ }^{-}-\mathrm{N}_{e}+\mathrm{NO}_{2}{ }^{-}-\mathrm{N}_{e}+\mathrm{NH}_{4}{ }^{+}-\mathrm{N}_{e}\right)} .
\end{aligned}
$$

The concentrations of $\mathrm{NH}_{3}$ and $\mathrm{HNO}_{2}$ were calculated from the $\mathrm{NH}_{4}{ }^{+}-\mathrm{N}$ and $\mathrm{NO}_{2}{ }^{-}-\mathrm{N}$ concentrations inside the reactor, respectively, at the operating temperature and the $\mathrm{pH}$ value in the bulk liquid according to the expressions proposed by Hou et al. [15]. Ammonium and nitrite consumption rates were calculated from the profiles of ammonium and nitrite concentrations obtained in the reactor from the measurements performed throughout the operating cycles as described by Mosquera-Corral et al. [16].

\section{Results and Discussion}

3.1. Operation of the Reactor. The partial nitrification process was developed in the reactor after 25 days of operation (Stage I). The NAR, defined as the produced nitrite to ammonium removed ratio, was of $78 \%$ (Table 1 ). However, the achieved $\mathrm{NO}_{2}{ }^{-}-\mathrm{N} / \mathrm{NH}_{4}{ }^{+}-\mathrm{N}$ ratio in the effluent $(2.1 \mathrm{~g} / \mathrm{g})$ was higher than the required value of $1.3 \mathrm{~g} / \mathrm{g}$ which is considered optimal for the posttreatment of the effluent by means of the anammox process $[17,18]$. The very high nitrite production, with efficiencies larger than required, indicated the system was underloaded. On day 76, ALR was increased from 0.06 to $0.09 \mathrm{~g} \mathrm{NH}_{4}{ }^{+}-\mathrm{N} / \mathrm{L} \cdot \mathrm{d}$ (Stage II) in order to overload the system and, therefore, to obtain the desired $\mathrm{NO}_{2}{ }^{-}-\mathrm{N} / \mathrm{NH}_{4}{ }^{+}$$\mathrm{N}$ ratio. In these conditions the NAR remained almost constant $(83 \%)$ while the ammonium level in the effluent increased which allows obtaining a $\mathrm{NO}_{2}{ }^{-}-\mathrm{N} / \mathrm{NH}_{4}{ }^{+}-\mathrm{N}$ ratio in the effluent of $1.3 \mathrm{~g} / \mathrm{g}$. On day 160 (Stage II) a failure of the aeration system caused that the system operated under anoxic conditions for more than $48 \mathrm{~h}$ and nitrite concentration in the reactor decreased from around 200 to $100 \mathrm{mg} \mathrm{NO}_{2}^{-}$ N/L (Figure 2(a)). After this event the partial nitrification turned unstable and NAR diminished progressively while the nitrate concentration increased. In Stage III, the applied 


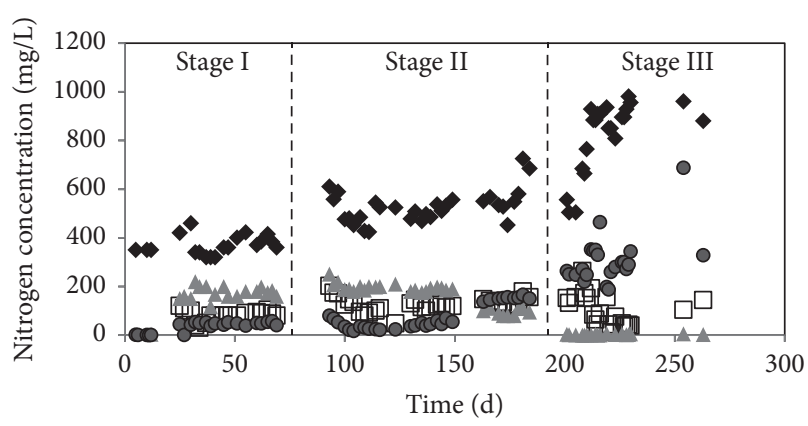

(a)

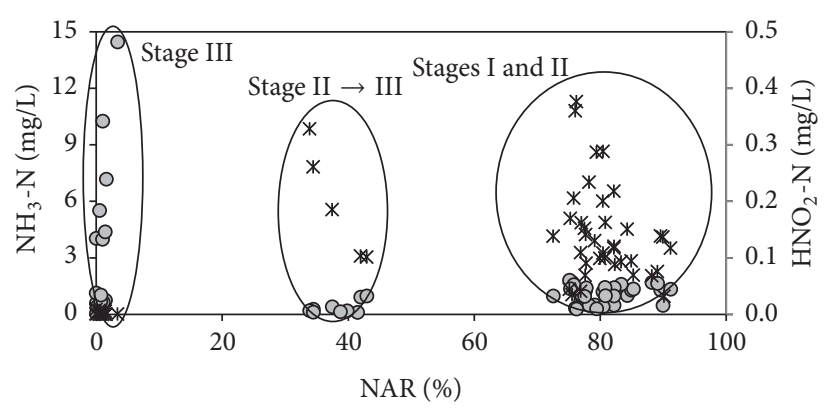

(b)

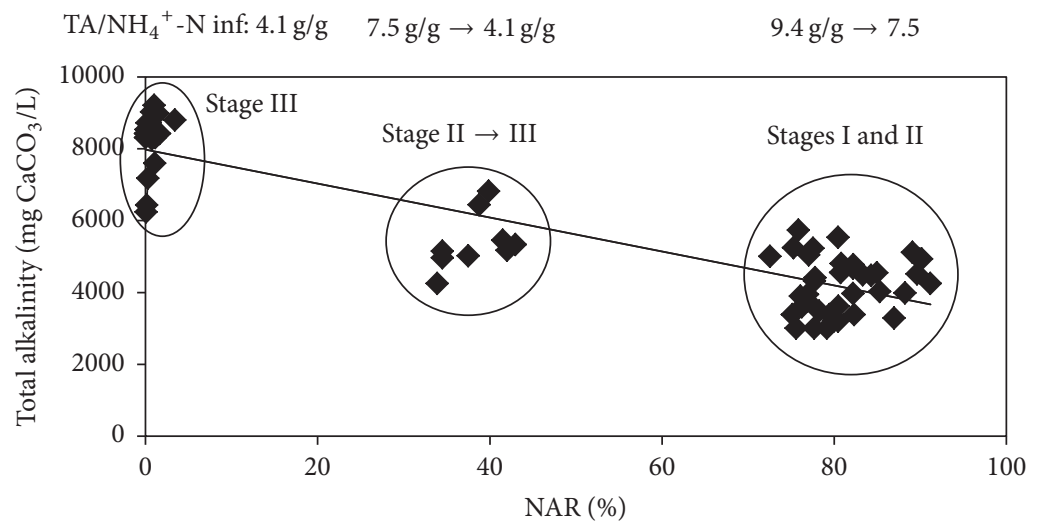

(c)

Figure 2: Evolution of nitrogen compounds. (a) Behavior of nitrogen concentration inside the reactor: $\mathrm{NH}_{4}{ }^{+}-\mathrm{N}$ influent $\left(\right.$ diamond), $\mathrm{NH}_{4}{ }^{+}-\mathrm{N}$ effluent (square), $\mathrm{NO}_{2}{ }^{-}-\mathrm{N}$ effluent (triangle), and $\mathrm{NO}_{3}{ }^{-}-\mathrm{N}$ effluent (circle). (b) Nitrite accumulation ratios (NAR) as percentages obtained at different $\mathrm{HNO}_{2}-\mathrm{N}$ (asterisk) and $\mathrm{NH}_{3}-\mathrm{N}$ (circle) concentrations. (c) Nitrite accumulation ratios (NAR) as percentages obtained at different total alkalinity influent (diamond) concentrations.

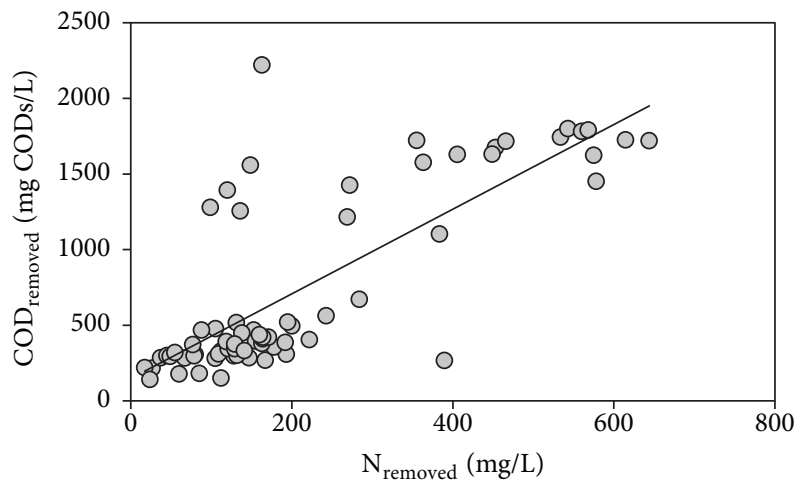

FIGURE 3: Relationship between $\mathrm{COD}_{\mathrm{S}}$ and $\mathrm{N}$ removed throughout the operational period.

ALR was increased up to $0.15 \mathrm{~g} \mathrm{NH}_{4}{ }^{+}-\mathrm{N} / \mathrm{L} \cdot \mathrm{d}$ with the aim of overloading the nitrifying microorganisms and, therefore, of accumulating nitrite, but the system was able to fully oxidize ammonium to nitrate at an efficiency of $86 \%$ and the previous partial nitrification conditions were not recovered. The destabilization of the PN that occurred on day 160 could be related to the prolonged anoxic period suffered by both $\mathrm{AOB}$ and NOB due the failure of the aeration system. According to Torà et al. [19], the activity of AOB would decrease around $14 \%$ after two days under anoxic conditions but the decrease expected for NOB activity would be higher than that of $\mathrm{AOB}$ activity due to the higher value of their decay constant [20]. Then, the effect the prolonged anoxic period on the loss of PN stability could be attributed to the decrease of nitrite concentration observed during this period.

In order to evaluate the possible reasons for the loss of nitrite accumulation, the FA and FNA concentrations were estimated for the different operational stages as shown in Figure 2(b). Collected results indicate that high NAR were obtained in the presence of FNA concentrations within 0.08-0.37 mg $\mathrm{HNO}_{2}-\mathrm{N} / \mathrm{L}$. These concentrations could be responsible for the inhibition of $\mathrm{NOB}$ and the consequent nitrite accumulation as it has been observed by authors like Park and Bae [21] and Kim and Seo [22]. On the contrary, no correlation between nitrite accumulation and FA concentrations calculated was detected. Ammonium was fully oxidized to nitrate even at FA concentrations higher than $3 \mathrm{mg} \mathrm{NH}-\mathrm{N} / \mathrm{L}$, a value which is generally reported as inhibitory for NOB [5, 21, 23]. Nevertheless, if biomass is adapted to the FA, the NOB inhibition can be only achieved

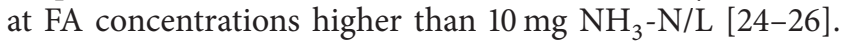




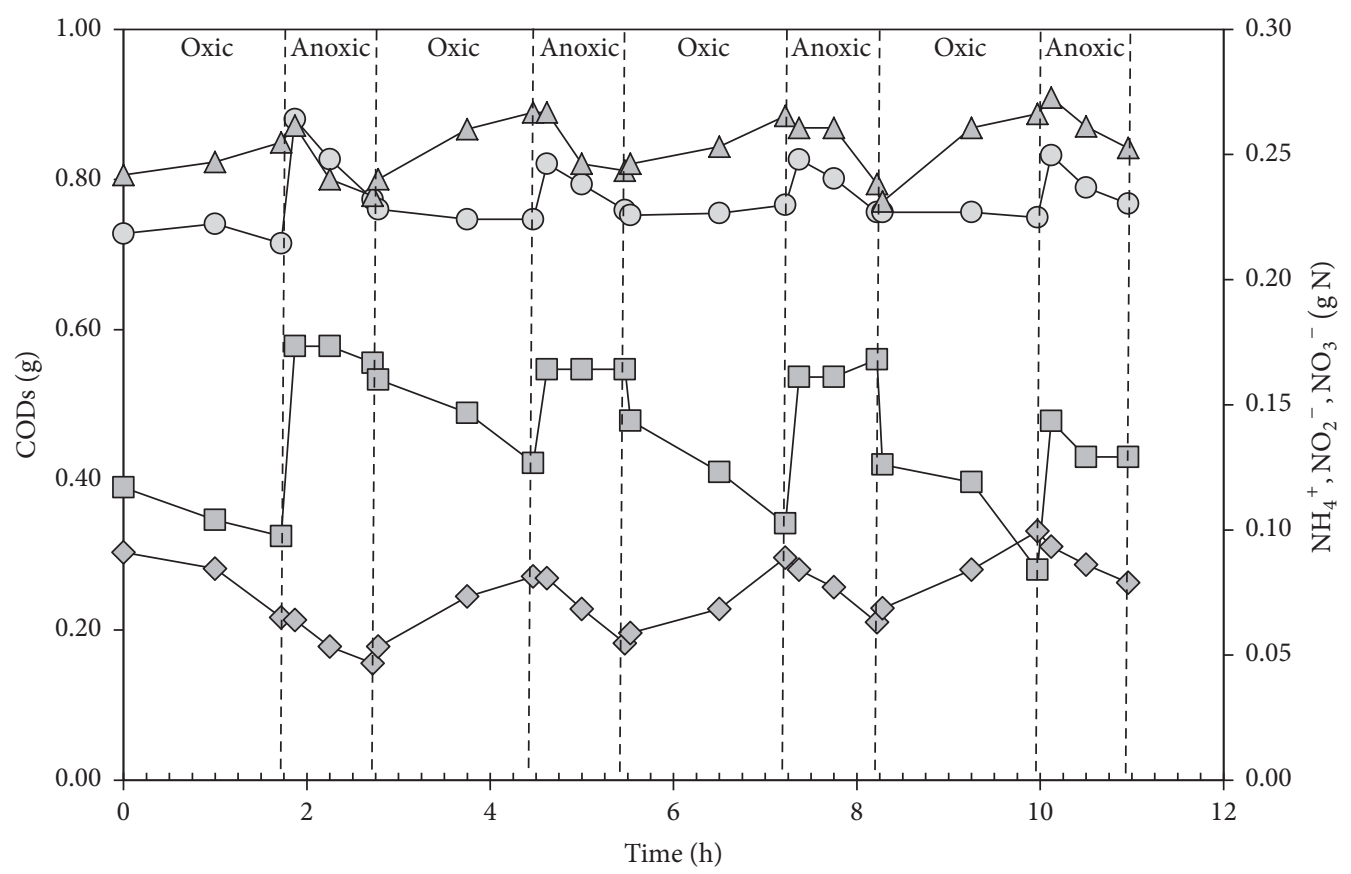

(a)

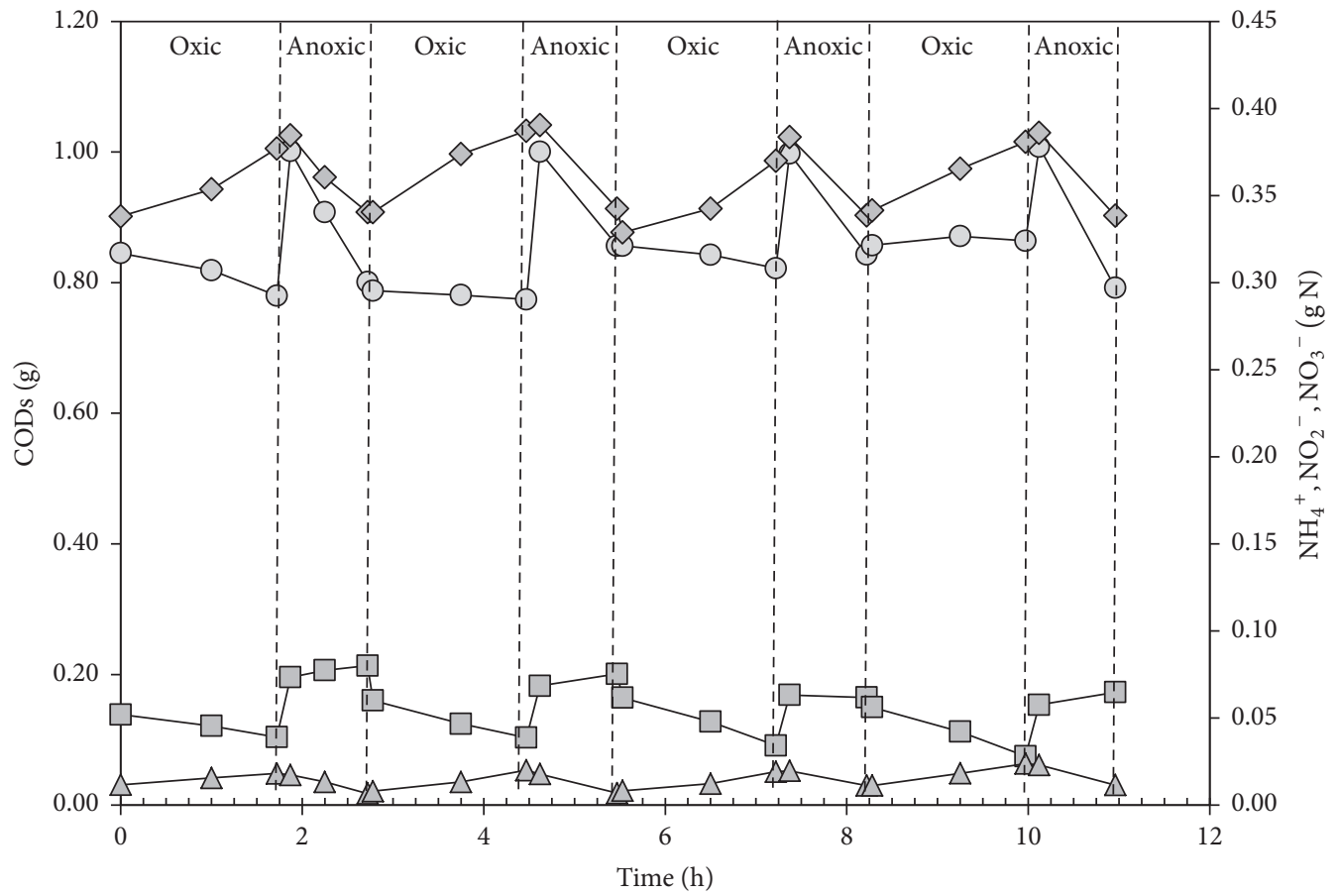

(b)

FIGURE 4: Evolution of $\mathrm{COD}_{\mathrm{S}}$ (circle), $\mathrm{NH}_{4}{ }^{+}-\mathrm{N}$ (square), $\mathrm{NO}_{2}{ }^{-}-\mathrm{N}$ (triangle), and $\mathrm{NO}_{3}{ }^{-}-\mathrm{N}$ (diamond) calculated amounts inside the reactor during an operational cycle in the SBR on days 109 (Stage II) (a) and 221 (Stage III) (b).

Results indicate that NAR was quickly lost once the inhibitory conditions for NOB were suppressed in Stage III. This would demonstrate that the inhibitory effects of FNA on NOB were temporary $[15,27]$.

Alkalinity is another important parameter that affects the nitrification process since it is important to maintain a suitable $\mathrm{pH}$ value [28]. Figure 2(c) shows that the decrease of the inlet total alkalinity concentrations increased the efficiency of the system in accumulating nitrite. This can be attributed to the decrease of $\mathrm{pH}$ value inside the reactor, which promoted the inhibitory effect of FNA on NOB (see Table 1). On the contrary, Hwang et al. [10] and Hou et al. [15] 
observed that nitrite was only accumulated when the inlet TA/ $\mathrm{NH}_{4}{ }^{+}-\mathrm{N}$ ratio was higher than the stoichiometric one (7.1 $\left.\mathrm{g} \mathrm{TA} / \mathrm{g} \mathrm{NH}_{4}{ }^{+}-\mathrm{N}\right)$ since this favoured the FA.

Respirometric assays were performed with biomass samples from the reactor. Experimental results confirmed the observations from the reactor operation. The initial NOB specific activity decreased to no detectable levels on day 25 and remained at this level until day 187. These results were related to the increase in the FNA concentration and its inhibitory effect on NOB (Figure 2(b)). From this day on, NOB specific activity gradually increased up to a value of $230 \mathrm{mg} \mathrm{NO}_{2}{ }^{-}-\mathrm{N} / \mathrm{g}$ VSS.d. The AOB specific activity was of

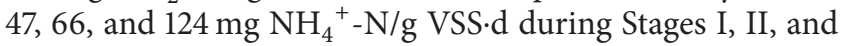
III, respectively. The SDA of the biomass was of $120 \mathrm{mg} \mathrm{N} / \mathrm{g}$ VSS. $d$ during the whole operational period.

The COD removal efficiency was affected by the influent quality and ranged from 39\% during Stage I to 85\% during Stage III. Concerning nitrogen removal efficiency, its value ranged from $21 \%$ (Stage I) to $47 \%$ (Stage III) (Table 1). Results showed a clear relationship between the amounts of organic matter and nitrogen removed, which indicate that the denitrification process was taking place (Figure 3). During Stage II, the $\mathrm{COD}_{\text {removed }} / \mathrm{N}_{\text {removed }}$ ratio was of $2.6 \mathrm{~g} / \mathrm{g}$ while, during Stage III, this ratio increased up to $3.5 \mathrm{~g} / \mathrm{g}$ because ammonium was completely oxidized to nitrate during this stage [29].

3.2. Operational Cycles. In order to evaluate the performance of the reactor, cycle measurements were carried out. The $\mathrm{COD}_{\mathrm{S}}$ and nitrogenous compounds concentrations were measured throughout different operational cycles over the operational period. Data obtained from the cycle measurements of days 109 (Stage II) and 221 (Stage III) are shown in Figure 4 in terms of accumulative amounts (g) of the measured compounds. In both cycles, biodegradable organic matter was mainly removed during the anoxic phases together with nitrite and nitrate while $\mathrm{COD}_{\mathrm{S}}$ remained practically constant during oxic phases. These profiles show that the cycle distribution allows the efficient use of the organic matter, contained in the influent, to carry out denitrification. Therefore, the nitrogen load to be treated in a subsequent anammox reactor decreases. The main difference between both measured cycles was the relative values of ammonium and nitrite oxidation rates. On day 109, the ammonium oxidation rate was 3 to 4 times larger than the nitrite oxidation rate, while on day 229 , both values were almost the same thus indicating that the partial nitrification was not possible during the last stage.

Gilbert et al. [30] observed the appearance of a lag phase longer for the nitrite oxidation than for the ammonia oxidation when anoxic periods, longer than 15-20 minutes, were imposed. However the lag phase corresponding to the nitrite oxidation had been always lower than 12 minutes. Therefore, the operational cycle distribution used in this work would not be suitable to promote PN due to the long duration of the oxic period (105 minutes). In fact, when alternating oxic/anoxic conditions are applied to avoid the nitrite oxidation during municipal wastewater treatment by means of continuous systems, where neither FA nor FNA inhibitions are expected, the length of the oxic and anoxic periods is fixed at around 10 minutes [4, 29, 31].

\section{Conclusions}

Stable partial nitrification was achieved during the treatment of the effluent of an anaerobic reactor fed with pig slurry. Since the system was operated at high STR values (15-20 d) and nonlimiting oxygen concentrations (higher than $3 \mathrm{mg}$ $\mathrm{O}_{2} / \mathrm{L}$ ), nitrite accumulation was mainly attributed to the presence of high FNA concentrations. Attempts to inhibit NOB by promoting the presence of FA were not successful.

\section{Conflicts of Interest}

The authors declare that there are no conflicts of interest regarding the publication and financing the publication of this paper.

\section{Acknowledgments}

This work was funded by the Chilean Government (CONICYT/FONDECYT 3140276, CONICYT/PAI/MEC 80140011, FDD-UPLA-CC18105, Patagonia Seed Project 210.310.055-1SP, CONICYT/FONDAP/15130015, and Red Doctoral REDOC.CTA, MINEDUC Grant UCO1202 at University of Concepción). The authors thank Mr. C. Contreras from "Sucesión Yanine Abadi" for allowing the realization of this study in their facilities.

\section{References}

[1] B. Fridrich, D. Krčmar, B. Dalmacija et al., "Impact of wastewater from pig farm lagoons on the quality of local groundwater," Agricultural Water Management, vol. 135, pp. 40-53, 2014.

[2] D. C. Rodriguez, M. Belmonte, G. Peñuela, J. L. Campos, and G. Vidal, "Behaviour of molecular weight distribution for the liquid fraction of pig slurry treated by anaerobic digestion," Environmental Technology, vol. 32, no. 4, pp. 419-425, 2011.

[3] S. Lackner, A. Terada, and B. F. Smets, "Heterotrophic activity compromises autotrophic nitrogen removal in membraneaerated biofilms: Results of a modeling study," Water Research, vol. 42, no. 4-5, pp. 1102-1112, 2008.

[4] B. Wett, A. Omari, S. M. Podmirseg et al., "Going for mainstream deammonification from bench to full scale for maximized resource efficiency," Water Science and Technology, vol. 68, no. 2, pp. 283-289, 2013.

[5] A. C. Anthonisen, R. C. Loehr, T. B. S. Prakasam, and E. G. Srinath, "Inhibition of nitrification by ammonia and nitrous acid," Research Journal Water Pollution Control, vol. 48, no. 5, pp. S35-S52, 1976.

[6] J. S. Almeida, S. M. Júlio, M. A. M. Reis, and M. J. T. Carrondo, "Nitrite inhibition of denitrification by Pseudomonas fluorescens," Biotechnology and Bioengineering, vol. 46, no. 3, pp. 194-201, 1995.

[7] Y. Zhou, A. Oehmen, M. Lim, V. Vadivelu, and W. J. Ng, "The role of nitrite and free nitrous acid (FNA) in wastewater treatment plants," Water Research, vol. 45, no. 15, pp. 4672-4682, 2011. 
[8] U. Durán, A. Val Del Río, J. L. Campos, A. Mosquera-Corral, and R. Méndez, "Enhanced ammonia removal at room temperature by $\mathrm{pH}$ controlled partial nitrification and subsequent anaerobic ammonium oxidation," Environmental Technology (United Kingdom), vol. 35, no. 4, pp. 383-390, 2014.

[9] L. Zhang, J. Yang, D. Hira, T. Fujii, and K. Furukawa, "High-rate partial nitrification treatment of reject water as a pretreatment for anaerobic ammonium oxidation (anammox)," Bioresource Technology, vol. 102, no. 4, pp. 3761-3767, 2011.

[10] B.-H. Hwang, K.-Y. Hwang, E.-S. Choi, D.-K. Choi, and J.-Y. Jung, "Enhanced nitrite build-up in proportion to increasing alklinity $/ \mathrm{NH}_{4}{ }^{+}$ratio of influent in biofilm reactor," Biotechnology Letters, vol. 22, no. 16, pp. 1287-1290, 2000.

[11] J. López-Fiuza, B. Buys, A. Mosquera-Corral, F. Omil, and R. Méndez, "Toxic effects exerted on methanogenic, nitrifying and denitrifying bacteria by chemicals used in a milk analysis laboratory," Enzyme and Microbial Technology, vol. 31, no. 7, pp. 976-985, 2002.

[12] B. R. Buys, A. Mosquera-Corral, M. Sánchez, and R. Méndez, "Development and application of a denitrification test based on gas production," Water Science and Technology, vol. 41, no. 12, pp. 113-120, 2000.

[13] APHA-AWWA-WPCF, Standard Methods for Examination of Water and Wastewater, 21st edition, 2005.

[14] L. E. Ripley, W. C. Boyle, and J. C. Converse, "Improved alkalimetric monitoring for anaerobic digestion of high-strength wastes," Journal of the Water Pollution Control Federation, vol. 58, no. 5, pp. 406-411, 1986.

[15] B. Hou, H. Han, S. Jia, H. Zhuang, Q. Zhao, and P. Xu, "Effect of alkalinity on nitrite accumulation in treatment of coal chemical industry wastewater using moving bed biofilm reactor," Journal of Environmental Sciences (China), vol. 26, no. 5, pp. 1014-1022, 2014.

[16] A. Mosquera-Corral, M. K. De Kreuk, J. J. Heijnen, and M. C. M. Van Loosdrecht, "Effects of oxygen concentration on Nremoval in an aerobic granular sludge reactor," Water Research, vol. 39, no. 12, pp. 2676-2686, 2005.

[17] Y.-H. Ahn, "Sustainable nitrogen elimination biotechnologies: a review," Process Biochemistry, vol. 41, no. 8, pp. 1709-1721, 2006.

[18] J. Vázquez-Padín, I. Fernádez, M. Figueroa, A. MosqueraCorral, J.-L. Campos, and R. Méndez, "Applications of Anammox based processes to treat anaerobic digester supernatant at room temperature," Bioresource Technology, vol. 100, no. 12, pp. 2988-2994, 2009.

[19] J. A. Torà, J. Lafuente, J. A. Baeza, and J. Carrera, "Longterm starvation and subsequent reactivation of a high-rate partial nitrification activated sludge pilot plant," Bioresource Technology, vol. 102, no. 21, pp. 9870-9875, 2011.

[20] G. Munz, C. Lubello, and J. A. Oleszkiewicz, "Factors affecting the growth rates of ammonium and nitrite oxidizing bacteria," Chemosphere, vol. 83, no. 5, pp. 720-725, 2011.

[21] S. Park and W. Bae, "Modeling kinetics of ammonium oxidation and nitrite oxidation under simultaneous inhibition by free ammonia and free nitrous acid," Process Biochemistry, vol. 44, no. 6, pp. 631-640, 2009.

[22] D.-J. Kim and D. Seo, "Selective enrichment and granulation of ammonia oxidizers in a sequencing batch airlift reactor," Process Biochemistry, vol. 41, no. 5, pp. 1055-1062, 2006.

[23] J. Li, D. Elliott, M. Nielsen, M. G. Healy, and X. Zhan, "Longterm partial nitrification in an intermittently aerated sequencing batch reactor (SBR) treating ammonium-rich wastewater under controlled oxygen-limited conditions," Biochemical Engineering Journal, vol. 55, no. 3, pp. 215-222, 2011.

[24] A. Spagni and S. Marsili-Libelli, "Nitrogen removal via nitrite in a sequencing batch reactor treating sanitary landfill leachate," Bioresource Technology, vol. 100, no. 2, pp. 609-614, 2009.

[25] M. Belmonte, C.-F. Hsieh, C. Figueroa, J. L. Campos, and G. Vidal, "Effect of free ammonia nitrogen on the methanogenic activity of swine wastewater," Electronic Journal of Biotechnology, vol. 14, no. 3, 2011.

[26] J. W. Shanahan and M. J. Semmens, "Alkalinity and pH effects on nitrification in a membrane aerated bioreactor: an experimental and model analysis," Water Research, vol. 74, pp. 10-22, 2015.

[27] L.-Y. Chai, M. Ali, X.-B. Min et al., "Partial nitrification in an air-lift reactor with long-term feeding of increasing ammonium concentrations," Bioresource Technology, vol. 185, pp. 134-142, 2015.

[28] M. Pijuan, L. Ye, and Z. Yuan, "Free nitrous acid inhibition on the aerobic metabolism of poly-phosphate accumulating organisms," Water Research, vol. 44, no. 20, pp. 6063-6072, 2010.

[29] S. Ge, Y. Peng, S. Qiu, A. Zhu, and N. Ren, "Complete nitrogen removal from municipal wastewater via partial nitrification by appropriately alternating anoxic/aerobic conditions in a continuous plug-flow step feed process," Water Research, vol. 55, pp. 95-105, 2014.

[30] E. M. Gilbert, S. Agrawal, F. Brunner, T. Schwartz, H. Horn, and S. Lackner, "Response of different Nitrospira Species to anoxic periods depends on operational DO," Environmental Science and Technology, vol. 48, no. 5, pp. 2934-2941, 2014.

[31] P. Regmi, M. W. Miller, B. Holgate et al., "Control of aeration, aerobic SRT and COD input for mainstream nitritation/denitritation," Water Research, vol. 57, pp. 162-171, 2014. 

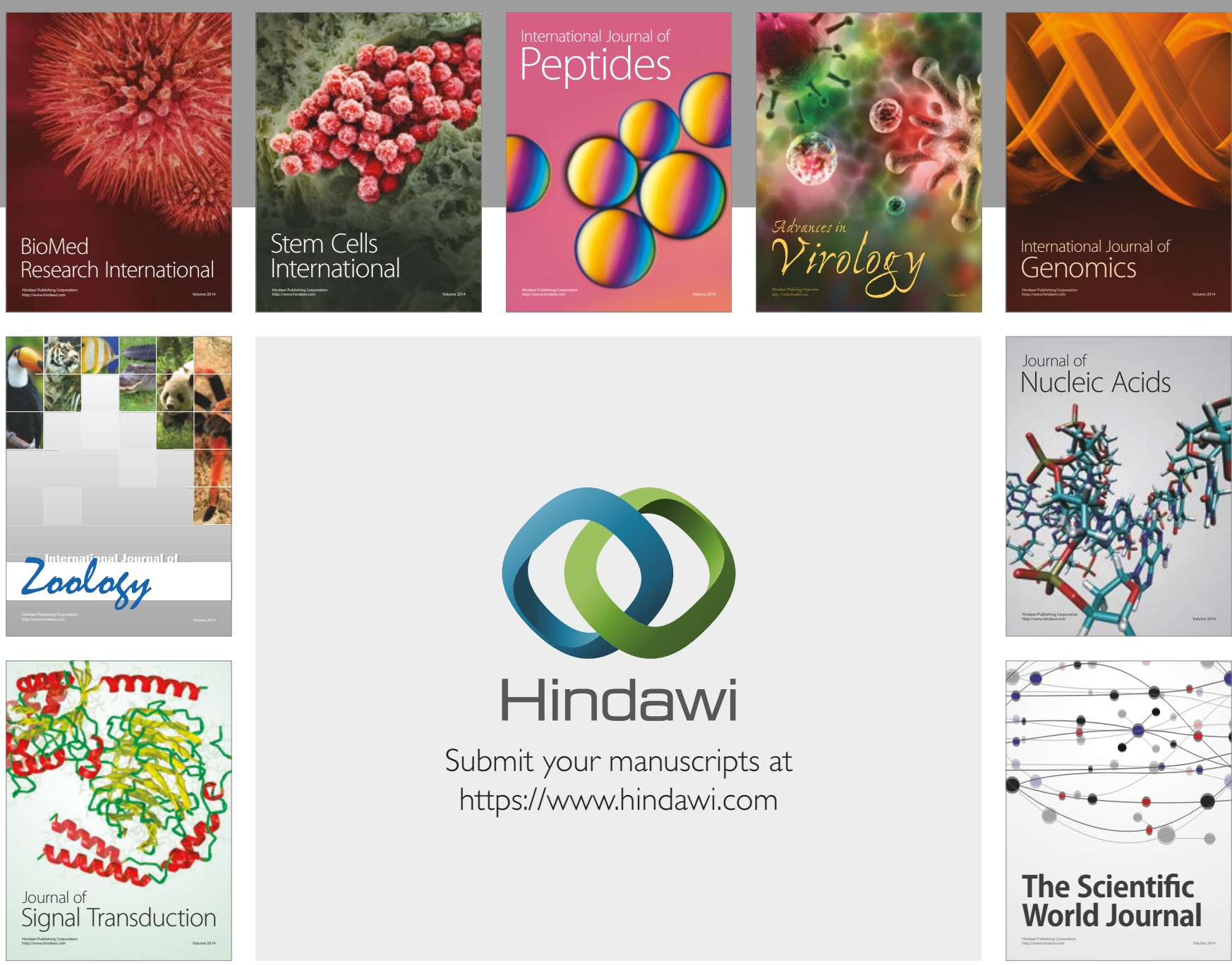

Submit your manuscripts at

https://www.hindawi.com
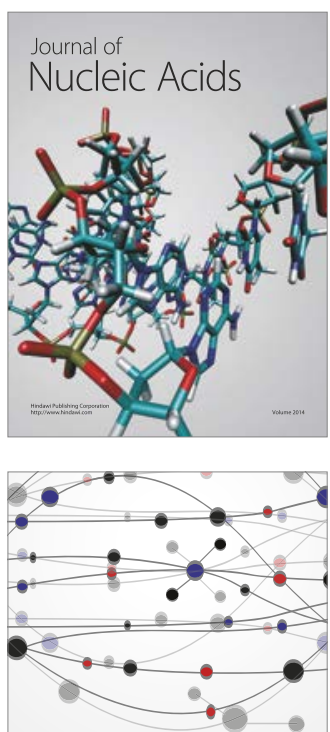

The Scientific World Journal

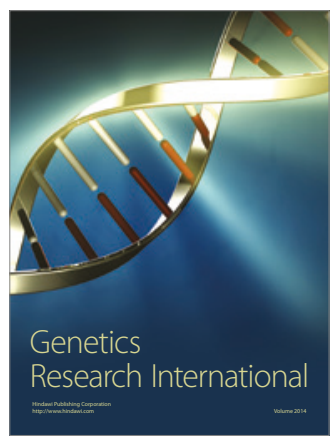

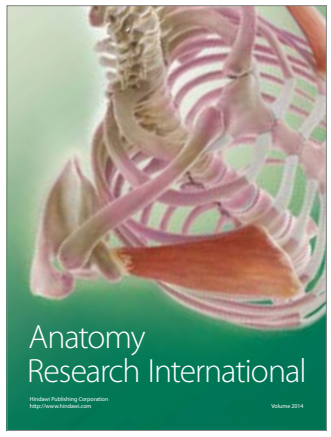

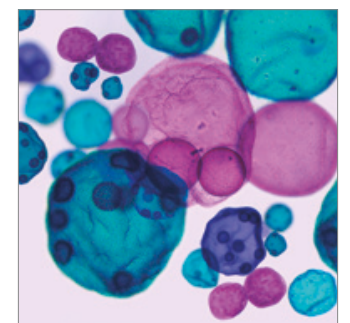

International Journal of Microbiology
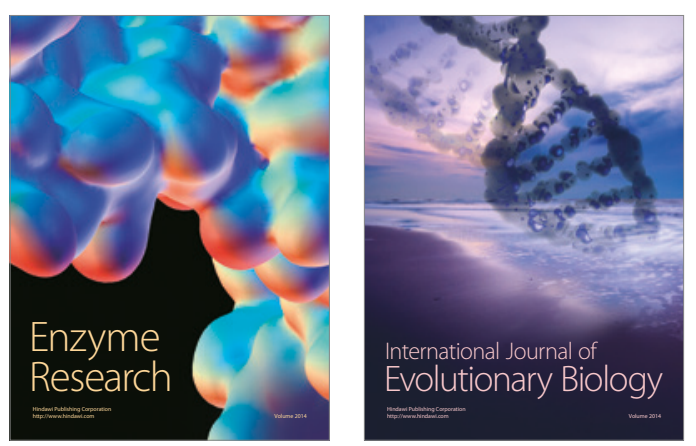
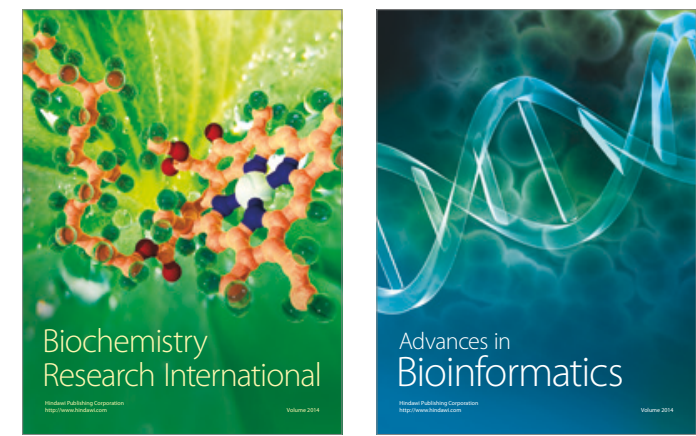

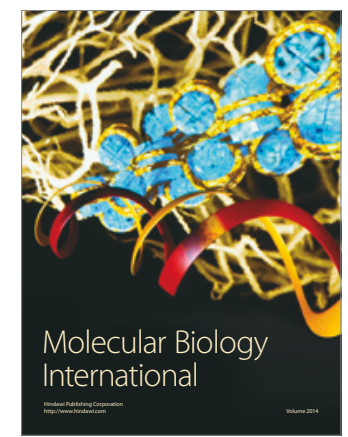

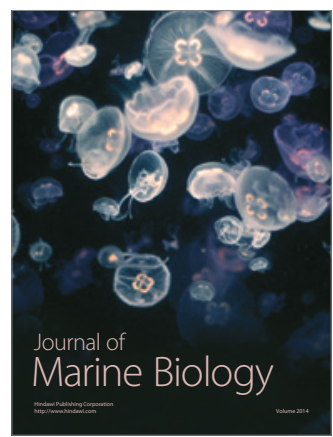

